\title{
A Unique Formulation of Cardioprotective Bio-Actives: An Overview of Their Safety Profile
}

\author{
William Salminen ${ }^{1}$, Mayowa Agbaje-Williams ${ }^{2, *}$ and Funmilayo O. Ajayi ${ }^{3}$ \\ 1 Camargo Pharmaceutical Services, Cincinnati, OH 45242, USA; wsalminen@camargopharma.com \\ 2 Clinical Scientist Group LLC, Phoenix, AZ 85286, USA \\ 3 Annesway Consulting Group LLC, Springboro, OH 45066, USA; ajayifa@yahoo.com \\ * Correspondence: mayowa@csgbio.com
}

Received: 3 September 2019; Accepted: 17 October 2019; Published: 22 October 2019

\begin{abstract}
The burden of cardiovascular disease (CVD) remains high globally and in the United States despite the availability of pharmaceuticals aimed at its prevention and treatment. An invention by Summit Innovation Labs, which is a formula consisting of a unique blend of select polyphenols (i.e., curcumin, quercetin, resveratrol), vitamin K2 as menaquinone-7, and magnesium, was recently developed to modulate the impact of the specific drivers of CVD, namely, vascular calcification, oxidative stress, and chronic inflammation. The SIL formulation is a dietary supplement that was designed leveraging the more bioavailable forms of ingredients with poor absorption, such as curcumin and quercetin. Each ingredient within the SIL formulation has been shown to contribute to CVD risk reduction by moderating the effect of CVD triggers, thereby providing a holistic prevention strategy for CVD in the healthy population. This review focuses on recently published clinical data to support the safety profile of these ingredients following oral administration. The preponderance of clinical trial data reviewed support the overall safety of the bioactives when used singly or in combination. The most commonly reported adverse effects were generally mild dose-related gastrointestinal disturbances, which may be alleviated with diet in some cases. In light of these, we conclude that the combination of the ingredients in the SIL formulation is reasonably expected to be safe.
\end{abstract}

Keywords: cardiovascular disease; polyphenols; vascular calcification; oxidative stress; inflammation

\section{Introduction}

Globally, one-third of the more than 54 million deaths in 2013 were attributed to cardiovascular disease (CVD) [1]. Similarly, in the United States, although there was a decrease in CVD mortality between 2000 and 2014, heart disease remains the leading cause of death, with an annual mortality rate of $25 \%$ [2,3] despite the availability of myriad pharmacological interventions for the prevention and treatment of heart disease.

Although the mortality rate due to CVD decreased in the past two decades (1990-2013), the global burden of CVD increased roughly during the same period (1990-2010) [1,4,5]. Of note is the increase in the number of CVD deaths, particularly in low to middle income countries, owing to the increasing growth and aging of the global population [1]. More alarming, however, is the deceleration in the rate of CVD mortality decline and the possibility that the decline may stop or even reverse course [6].

Ischemic heart disease has been shown to be the main driver of CVD burden according to the 2010 global burden of disease study [5]. It is caused by the presence of atherosclerosis in the coronary arteries [7]. The development of atherosclerosis in CVD is a multifactorial process thought to be initiated by the presence of oxidized low-density lipoprotein (LDL) particles and their penetration of the endothelial barrier [8]. Oxidized LDL particles signal the recruitment of chemokines and 
inflammatory mediators, leading to formation of atherosclerotic plaques. In addition to oxidative stress, inflammation and endothelial dysfunction are also recognized pathogenic pathways in CVD development $[9,10]$.

These pathways have been associated with the development of vascular calcification (VC), a major risk factor for atherosclerosis [11-13]. VC is distinguished by the presence of calcium deposits in the vasculature leading to reduced elasticity and compliance of the vessel wall, with potential increased risk of death [11,14].

A formulation (SIL) consisting of a unique blend of plant phytonutrients comprising primarily polyphenols (PPs), vitamins, minerals, and other natural bioactive ingredients was recently developed to mitigate oxidative stress and chronic inflammation. PPs have been key components of the human diet for centuries, and within the past couple of decades have been a focus of scientific research geared towards the evaluation of their therapeutic potential against myriad diseases [15]. For instance, diets rich in PPs such as the Mediterranean diet have been linked to a reduced risk of major CV events [16].

The SIL formulation, a dietary supplement developed to modulate the progression of CVD by harnessing the cardiac-health-promoting benefits of PPs, is expected to yield better systemic exposure compared to that following food consumption since culinary preparation such as peeling and boiling is known to significantly reduce the PP content of foods $[17,18]$. Furthermore, because there are a variety of PPs in food and due to the challenges in the quantitation of individual PPs in certain foods, it is difficult to pinpoint a specific plant source that contains all key PPs that may mitigate CVD [19]. As such, the SIL formulation consists of the following select PPs based on their purported cardioprotective activity in the following daily dose ranges: curcumin 30-150 mg, quercetin 20-100 mg, resveratrol 50-250 mg; as well as vitamin K2 (as menaquinone-7) 30-360 $\mu$ g, and magnesium 50-300 mg. The dose ranges selected for curcumin and quercetin were reduced by a factor of 5 to 10 given the improved bioavailability conferred by the dose form of these ingredients as discussed below.

PPs are a diverse group of naturally occurring substances that are abundantly present in higher plants and consequently in the human diet [17]. The polyphenolic chemical structure is distinguished by aromatic rings bound to multiple hydroxyl groups [17,19].

PPs are believed to possess cardioprotective effects, in part due to their antioxidant properties conferred by the presence of the phenolic hydroxyl groups, which scavenge reactive oxygen species (ROS) $[19,20]$. The consumption of a polyphenol-rich diet has been shown to lower LDL oxidation-an initiative step in the development of atherosclerosis [15,21]. In addition, anti-inflammatory properties of PPs are manifested in their modulation of signaling pathways and the adhesive interaction between the vasculature and immune system - a process that is key to plaque formation [15,19].

As will be discussed below, each of the ingredients in the SIL formulation have been shown to impact the effect of one or more of the drivers of CVD, and collectively they provide a holistic means of maintaining optimal cardiovascular health.

The purpose of this article is to review the safety of each of these ingredients following oral administration.

\section{Literature Review Strategy}

First, ingredients were reviewed from a regulatory standpoint by considering Food and Drug Administration (FDA) safety requirements, including the Dietary Supplement Health and Education Act (DSHEA) of 15 October 1994. According to DSHEA, an ingredient marketed prior to 15 October 1994 is not considered a new dietary ingredient and does not require the submission of a premarket notification (safety data) to the FDA at least 75 days before marketing the product. To determine if an ingredient is considered an "old dietary" ingredient, the United Natural Products Alliance (UNPA) published a compilation of old dietary ingredients in 2008 to be used as a reference tool. A caveat is that the FDA has not verified the accuracy of the list and as such may reserve the right to require that 
the company submit safety data. Each ingredient in the SIL formulation was reviewed to see if it is present on the UNPA list and or in currently marketed DSHEA products at the same or higher doses.

Secondly, an in-depth review of the safety and efficacy data on each ingredient in the formulation was performed by searching for literature articles primarily on MEDLINE, PubMed, and Google Scholar; or from internet searches using Google; as well as citations from relevant review articles on each ingredient. Search terms employed included but were not limited to ingredient name, safety, side effects, clinical trial, and adverse effects. Articles were included if they were published in the last 10 years and contained information on the safety and tolerability of each ingredient when administered orally to human subjects. Select articles published outside of the 10-year window were included if they contained pertinent safety information. A number of clinical studies evaluating the safety and efficacy of these ingredients have been conducted in a variety of indications.

\section{Curcumin}

Curcumin, shown in Figure 1, is one of the major and most potent curcuminoids present in the Indian spice turmeric, the powdered rhizome of the plant Curcuma longa [23,24]. Other curcuminoids are demethoxycurcumin and bisdemethoxycurcumin [24]. Curcumin can be derived from turmeric by solvent extraction, and the ensuing extract is then purified by crystallization [25].

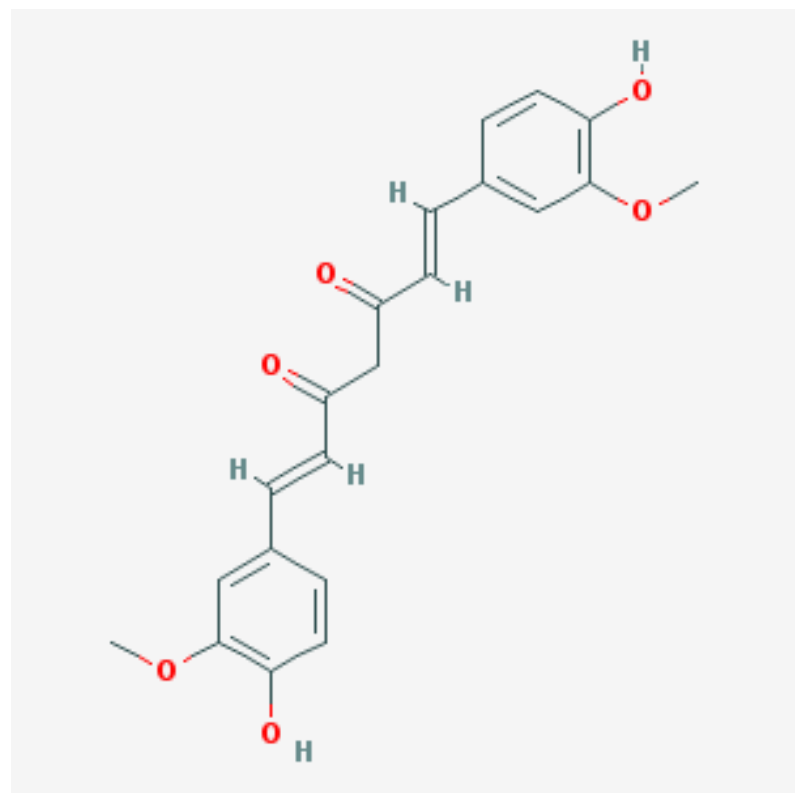

458-37-7

Figure 1. Chemical structure of curcumin with chemical abstracts service registry number (CASRN) [22].

Curcumin has been used for more than 5000 years in India not only as a food flavoring and coloring agent, but also for its medicinal properties, which include but are not limited to anti-inflammatory, antioxidant, anti-infective, antidepressant, antispasmodic, and wound-healing effects [24]. A preponderance of literature suggests an activity of curcumin against inflammatory disease states such as osteoarthritis [26], autoimmune diseases such as rheumatoid arthritis [27], ulcerative colitis [28], malignant conditions [29,30], diabetes mellitus [31], and cardiovascular diseases [32].

Because of its hydrophobicity, it is highly insoluble with low oral bioavailability [24]. However, it is soluble in dimethylsulfoxide, acetone, ethanol, and oils [24]. A number of measures have been employed to increase the bioavailability of curcumin. These include formulating it as a nanoparticle [33], in liposomes [34], in phospholipids such as lecithin [35], or with piperine, the active ingredient of 
black pepper [36]. Piperine was found to improve the bioavailability of curcumin by about $2000 \%$, possibly by the inhibition of glucuronidation in the liver and small intestine [36].

In the SIL formulation, curcumin is delivered as theracurmin, a nanoparticle colloidal dispersion synthesized by mixing curcumin powder in gum ghatti solution with water and glycerin and then dispersing with a high-pressure homogenizer [33]. The formulation of curcumin as theracurmin increases the bioavailability of curcumin in rats and humans by at least 27 -fold, ensuring efficacy at a relatively low dose within the SIL formulation.

\section{Safety Profile from Clinical Studies on Curcumin}

The studies of curcumin reviewed in Table 1 consisted of a wide variety of subject populations ranging from relatively healthy to critically ill in a primarily adult population. One study of curcumin in a pediatric population was also included to support the wide margin of safety of curcumin across different populations. Additionally, the doses evaluated in the reported studies ranged from 500 to $12,000 \mathrm{mg}$.

Table 1. Summary of Safety Profile of Curcumin.

\begin{tabular}{|c|c|c|c|c|c|c|c|}
\hline Reference & Year & $\begin{array}{l}\text { Study } \\
\text { Design }\end{array}$ & $\begin{array}{l}\text { Duration } \\
\text { (months) }\end{array}$ & $\mathbf{N}$ & Study Population & Dose (mg) & Safety Result \\
\hline$[32]$ & 2015 & $\mathrm{RCT}$ & 2 & 33 & $\begin{array}{c}\text { Coronary artery } \\
\text { disease }\end{array}$ & 2000 & $\begin{array}{l}\text { GI AEs (diarrhea) reported in } \\
\text { two (2) subjects. This } \\
\text { resolved with curcumin } \\
\text { admin. after meal. }\end{array}$ \\
\hline [37] & 2017 & Open-label & 6 & 57 & $\begin{array}{l}\text { Healthy subjects } \\
\text { with low bone } \\
\text { density }\end{array}$ & 1000 & No AEs reported. \\
\hline [38] & 2014 & $\mathrm{RCT}$ & 1.5 & 40 & $\begin{array}{l}\text { Osteoarthritis of the } \\
\text { knee }\end{array}$ & 1500 & $\begin{array}{l}\text { Mild GI symptoms reported } \\
\text { in } 37 \%(7 / 19) \text { of subjects in } \\
\text { curcumin group vs. } 19 \% \\
\text { (4/21) of subjects in placebo } \\
\text { group. }\end{array}$ \\
\hline [39] & 2013 & $\begin{array}{c}\text { Dose } \\
\text { escalation }\end{array}$ & 6 & 11 & $\begin{array}{c}\text { Pediatric } \\
\text { inflammatory bowel } \\
\text { disease }\end{array}$ & $1000-4000$ & $\begin{array}{l}\text { Mild AEs: increased } \\
\text { gassiness; not attributed to } \\
\text { curcumin. }\end{array}$ \\
\hline [40] & 2001 & $\begin{array}{c}\text { Dose } \\
\text { escalation }\end{array}$ & 3 & & $\begin{array}{l}\text { Patients with high } \\
\text { risk or } \\
\text { pre-malignant } \\
\text { lesions }\end{array}$ & $500-12,000$ & $\begin{array}{l}\text { No treatment related AEs } \\
\text { reported up to } 8000 \mathrm{mg} / \text { day. } \\
12000 \mathrm{mg} / \text { day dose was } \\
\text { found intolerable due to the } \\
\text { large volume of the dose. }\end{array}$ \\
\hline [41] & 2006 & $\begin{array}{c}\text { Dose } \\
\text { escalation }\end{array}$ & $\begin{array}{l}\text { Single } \\
\text { dose }\end{array}$ & 24 & Healthy volunteer & $500-12,000$ & $\begin{array}{l}\text { Grade } 1 \text { AEs reported in } 30 \% \\
\text { (7/24) subjects: diarrhea, } \\
\text { headache, rash, yellow stool. } \\
\text { These did not appear to be } \\
\text { dose related. }\end{array}$ \\
\hline
\end{tabular}

The most common adverse effect of curcumin was gastrointestinal (GI) disturbance, which might be alleviated when taken with food or after a meal, as indicated in the study by Mirzabeigi et al. [32]. One efficacy study in an osteoarthritic population co-administered curcumin with other therapies such as non-steroidal anti-inflammatory drugs (NSAIDs, e.g., naproxen) [38], which are known for causing gastrointestinal (GI) side effects. As such, it is difficult to attribute the adverse event solely to curcumin in such studies. Nonetheless, GI side effects were most often reported in subjects that received curcumin alone.

The greatest exposure to curcumin occurred in a study that administered curcumin in a dose-escalating fashion up to $12,000 \mathrm{mg} /$ day for 3 months in patients with malignancy [40]. That study reported no adverse events up to $8000 \mathrm{mg} /$ day.

Given the long-term history of use and the wealth of data supporting an acceptable safety profile of curcumin at clinical doses up to $8000 \mathrm{mg}$ in both healthy and diseased populations, we conclude that curcumin supplied as theracurmin at doses ranging from 30 to $150 \mathrm{mg}$ per capsule in the SIL 
formulation is safe even when administered with agents that enhance its bioavailability. In addition, turmeric, the rhizome from which curcumin is derived, is recognized as an FDA approved food additive per 21CFR73.600, suggesting its suitability from a safety perspective for inclusion in the SIL formulation. Furthermore, Curcuma longa is listed on the UNPA list.

\section{Quercetin}

Also known as 3,5,7,3' $4^{\prime}$-pentahydroxyflavone, quercetin (Figure 2a) belongs to the flavonol class of flavonoids [46]. It is a phytochemical present in glycosylated form with close to 150 naturally occurring glycosides [47]. Some examples of quercetin glycosides are: rutin or quercetin-3-O- $\beta$-rutinoside (Figure $2 c$ ), isoquercitrin or quercitin-3-O- $\beta$-glucoside (Figure $2 b$ ), and quercitin-3,4'-O- $\beta$-diglucoside [45]. Quercetin aglycone (or free quercetin) can be derived by extraction of the glycosides from plants followed by hydrolysis [48]. It is abundant in onions, curly kale, leeks, broccoli, blueberries, tea, citrus fruits, grapes, etc. $[17,46]$. It is considered to be a potent antioxidant due to the presence of hydroxyl groups and double bonds in its structure (Figure 2) [42,46], and has been explored for its therapeutic potential in a variety of indications-particularly cancer and cardiovascular disease [49].

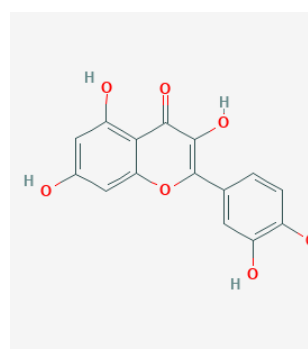

$117-39-5$

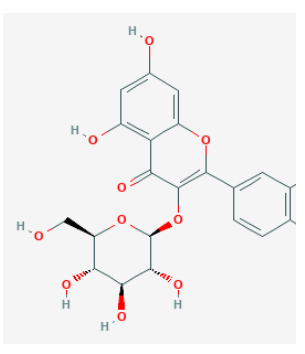

$482-35-9$

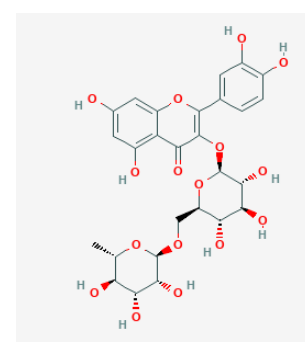

$153-18-4$

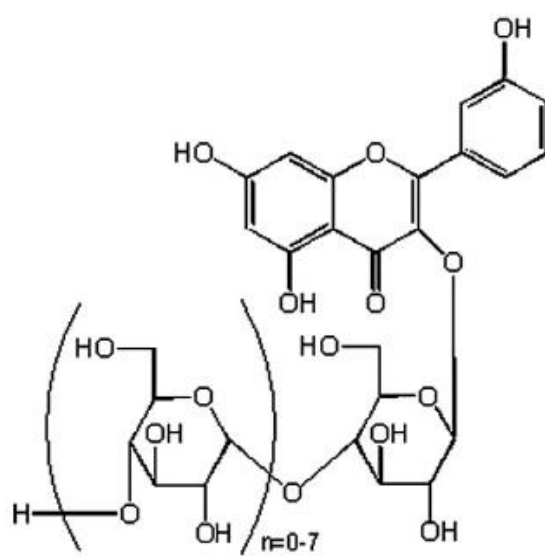

Not available

(a)

(b)

(c)

(d)

Figure 2. Chemical structures with CASRNs: (a) quercetin [42]; (b) Isoquercitrin (IQC) [43]; (c) Rutin [44]; (d) Enzymatically modified isoquercitrin (EMIQ) [45].

As previously mentioned, atherosclerosis is initiated by infiltration of the endothelial layer by oxidized LDL particles. Other potential contributing processes include reduction in endothelial nitric oxide production and impaired antithrombotic/antiplatelet activity [50,51]. Quercetin has been shown to mitigate the formation of atherosclerotic lesions, reduce markers of oxidative stress (F2-isoprostane), and increase endothelial nitric oxide synthase activity in apolipoprotein E knock-out mice [52]. Quercetin has also been shown in in vitro studies to possess antiplatelet activity and mitigate warfarin-induced vascular calcification $[46,53]$. This is important given that platelet aggregation and vascular calcifications are believed to contribute to plaque formation [11,54].

In light of these promising therapeutic potentials of quercetin, it is crucial to ensure the consistent delivery of adequate therapeutic levels. The bioavailability of quercetin varies depending on the sugar moiety attached, vehicle for administration, and food source [47]. For example, onions, which contain quercetin glucosides (a simpler sugar) provide higher quercetin bioavailability when compared to 
apples [55]. Co-administration with high-fat meals is also thought to improve the bioavailability of quercetin [47].

Quercetin's solubility is poor in water, but is increased in organic solvents or in solutions containing more than $30 \%$ ethanol [47]. A wide range of bioavailabilities has been reported for quercetin. This variability may be partly due to the method of analysis utilized, and the food matrix used for administration [56]. In one study conducted in healthy ileostomy subjects administered dried onions (89 mg aglycone), quercetin rutinoside, and quercetin aglycone (both containing $100 \mathrm{mg}$ quercetin aglycone), oral absorption of quercetin was respectively $52 \%, 17 \%$, and $24 \%$ [57]. Hollman et al. (1997) reported the oral bioavailability of quercetin from tea and apples to be $30 \%$ that of onions in nine (9) healthy subjects [55]. In general, it is believed that the oral bioavailability of quercetin aglycone is low, and that most of the quercetin in plasma is present in the form of glucuronide and sulfate conjugates $[56,58]$.

Efforts to increase quercetin bioavailability include co-administration with niacin and vitamin C, according to unpublished reports in animal studies by Quercegen Pharma [59]. Some currently marketed formulations consist of enzymatically modified isoquercitrin (EMIQ) and vitamin C. EMIQ or alpha-glycosyl isoquercitrin (Figure 2d), a derivative of rutin, was developed to improve the bioavailability of quercetin. It has been shown to increase plasma levels of quercetin metabolites after oral intake with higher absorption when compared to isoquercitrin and rutin [45]. In rats that were orally administered different quercetin glycosides, the bioavailability of quercetin was found to be $0.8 \%$, $2 \%, 12 \%, 30 \%$, and $35 \%$ when delivered as rutin, quercetin, isoquercitrin, quercetin-3-O-maltoside, and EMIQ, respectively [48].

\section{Safety Profile from Clinical Studies on Quercetin}

Quercetin is one the most studied flavonoids owing to its many potential biological activities [66]. In a detailed review of the safety of quercetin which evaluated results of in vitro, in vivo, preclinical, and clinical studies of quercetin, Harwood et al concluded that the available evidence supports the safety of quercetin for addition to food [56].

Studies of quercetin included in Table 2 spanned the past decade, and no adverse effects of quercetin were reported in all but one study. In that study, of the 1023 subjects enrolled, 667 received 500 or 1000 mg quercetin daily for 12 weeks and nine (9) subjects reported adverse symptoms [59]. Although details of the adverse events were not reported, the authors stated that there was no consistent pattern in the symptoms that were attributed to quercetin. Of note in this study, quercetin was administered with vitamin $C$ and niacin to improve its bioavailability. 
Table 2. Summary of Safety Profile of Quercetin.

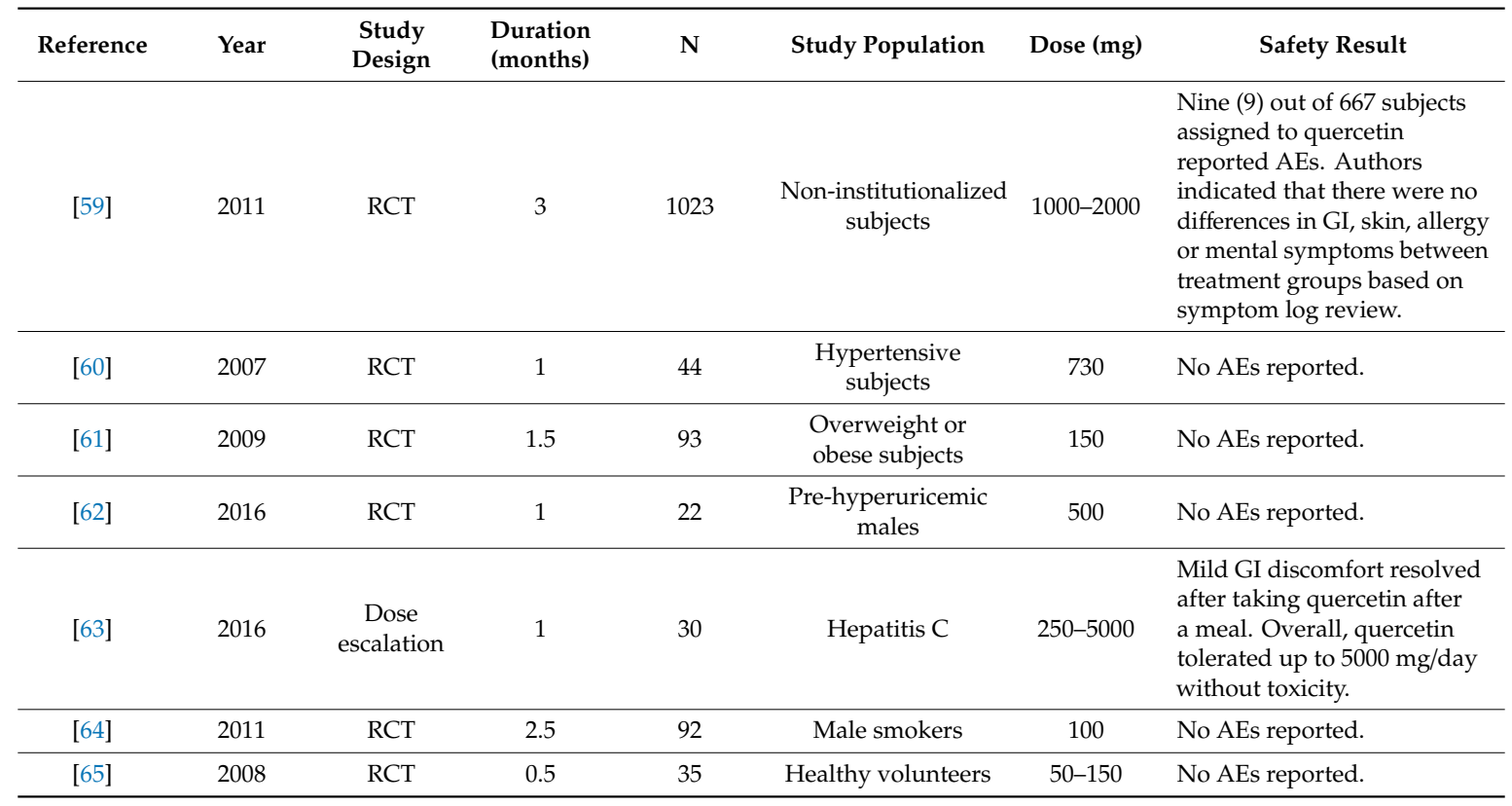

AE: adverse event; GI: gastrointestinal; RCT: randomized controlled trial.

Consistent with the detailed review by Harwood et al., which supports the safety of quercetin, and based on the recent studies evaluated in our review spanning doses from 100 to $2000 \mathrm{mg}$ with exposure over a period of 2 to 12 weeks, we conclude that quercetin is safe-especially when administered at the 20 to $100 \mathrm{mg}$ levels in the SIL formulation. In terms of safety considerations from a regulatory perspective, quercetin and rutin, the raw material from which EMIQ is derived, are listed on the UNPA list. In addition, EMIQ has been approved as a food additive in Japan and is present in a number of currently marketed dietary supplement products that can be purchased over the counter and over the internet $[47,67]$.

\section{Resveratrol}

Resveratrol, with chemical structure 3,5, $4^{\prime}$-trihydroxystilbene (illustrated in Figure 3), belongs to the stilbene class of polyphenols [69,70]. It is synthesized by plants in response to stressful stimuli [71]. Resveratrol is present as cis and trans isomers, and its conjugated derivative includes trans-resveratrol-3-O-glucoside. Although notably present in red wine, other significant dietary sources include Japanese knotweed (Polygonum cuspidatum), grapes, bilberry, and itadori tea [72]. 


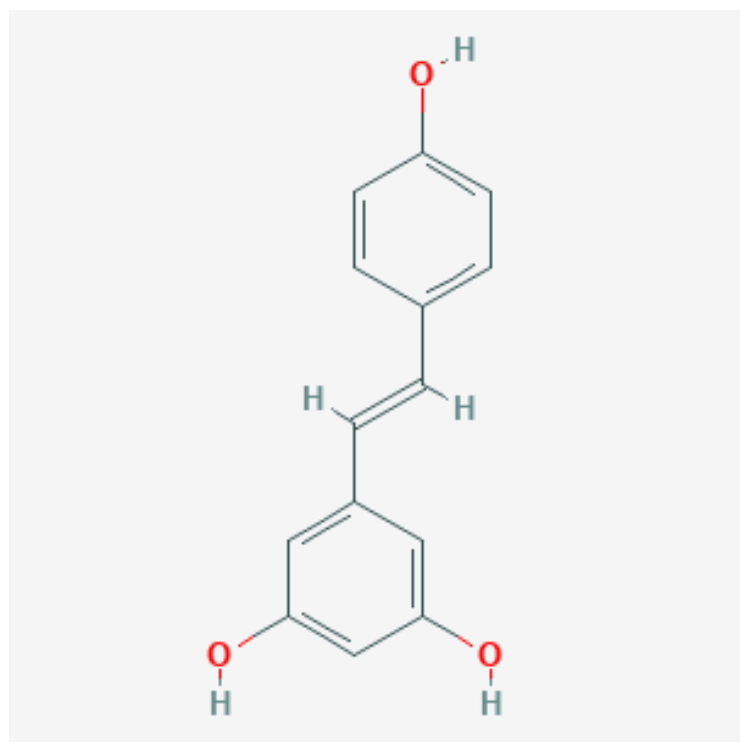

501-36-0.

Figure 3. Chemical structure of resveratrol with its CASRN [68].

Unlike most of the other polyphenols discussed in this review, resveratrol occurs in minimal concentrations in dietary sources $[17,19,69,72]$. As such, the delivery of an appreciable amount for potential pharmacological activity might require a nutraceutical formulation which is estimated to deliver up to 83-fold the supply from daily diet [72]. As a nutraceutical, it is usually delivered as $99 \%$ purified trans-RSV derived from the rhizome of the Japanese knotweed.

Resveratrol is noteworthy for the French paradox, a term coined to describe the cardioprotective benefit conferred by the French diet which comprises a high amount of red wine when compared to other countries, despite a concomitant high saturated fat intake [73]. The mechanisms proposed include lipid profile improvement and antiplatelet activity, both of which are important for attenuation of atherosclerosis. As a result, resveratrol has been studied extensively for mitigation of CVD risk factors [70,74].

Resveratrol possesses potent antioxidant and anti-inflammatory activity [19] — two biological activities that are germane to the cardioprotective benefits of polyphenols. Its benefits in CVD have been attributed to the reduction of LDL oxidation [75,76], improvement of lipid profile [71,77-79], antiplatelet activity [80], as well as antihypertensive and vasodilatory effects [81]. Its vasodilatory effects are believed to occur via improvement of endothelium-dependent vasodilation by increasing nitric oxide bioavailability [82].

As with other ingredients discussed in this review, resveratrol is limited by low bioavailability, which is likely due to its rapid metabolism [70,72]. In a pharmacokinetic study in which twelve (12) healthy males were randomized to receive trans-resveratrol, free resveratrol accounted for approximately $2 \%$ of the total concentration in plasma while the glucuronide and sulfate conjugates accounted for $>90 \%$ [83]. Unlike quercetin, whose absorption is facilitated by high fat intake, resveratrol absorption is impaired with increased fat in the diet [84].

\section{Safety Profile from Clinical Studies on Resveratrol}

As illustrated in Table 3, gastrointestinal adverse events, notably diarrhea, nausea, and abdominal discomfort, were most commonly reported in the studies of resveratrol reviewed. These were usually dose related, occurred more frequently with greater severity at doses above $1 \mathrm{~g}$, and occasionally led to treatment discontinuation. Although some of the studies were limited by small sample sizes, there is a consistent pattern in the reporting of dose-related GI symptoms. The mechanism of GI AE due to resveratrol remains unclear, though the formulation used could be a contributory factor [86]. 
Table 3. Summary of Safety Profile of Resveratrol.

\begin{tabular}{|c|c|c|c|c|c|c|c|}
\hline Reference & Year & $\begin{array}{l}\text { Study } \\
\text { Design }\end{array}$ & $\begin{array}{l}\text { Duration } \\
\text { (months) }\end{array}$ & $\mathbf{N}$ & Study Population & Dose (mg) & Safety Result \\
\hline [85] & 2015 & $\mathrm{RCT}$ & 12 months & 119 & $\begin{array}{l}\text { Mild to moderate } \\
\text { Alzheimer's disease }\end{array}$ & 2000 & $\begin{array}{l}\text { Nausea, diarrhea, and weight } \\
\text { loss were commonly reported } \\
\text { AEs which led to treatment } \\
\text { discontinuation. Subjects in } \\
\text { the placebo group gained } \\
0.54 \pm 0.32 \mathrm{~kg} \text { body weight } \\
\text { while resveratrol led to } \\
\text { a weight loss of } 0.92 \pm 4.9 \mathrm{~kg} \\
(P=0.038) .\end{array}$ \\
\hline [86] & 2015 & Open-label & 3 months & 24 & Friedrich ataxia & $\begin{array}{l}1000(\mathrm{LD}) \\
\text { or } 5000 \\
(\mathrm{HD})\end{array}$ & $\begin{array}{l}\text { Adverse GI events such as } \\
\text { diarrhea, loose stools, } \\
\text { abdominal pain, nausea, and } \\
\text { flatulence occurred at } \\
\text { a higher rate in the HD group. } \\
\text { Liver dysfunction leading to } \\
\text { treatment discontinuation } \\
\text { occurred in one (1) subject in } \\
\text { the HD group. Skin rash was } \\
\text { also reported in one (1) } \\
\text { subject in the HD group. }\end{array}$ \\
\hline [79] & 2015 & $\mathrm{RCT}$ & 3 months & 60 & NAFLD & 600 & No AEs were reported. \\
\hline [87] & 2014 & $\mathrm{RCT}$ & 1 month & 12 & Healthy subjects & 2000 & $\begin{array}{l}\text { Mild GI adverse events } \\
\text { occurred at a higher rate in } \\
\text { the resveratrol group when } \\
\text { compared to placebo. One (1) } \\
\text { subject on resveratrol } \\
\text { experienced pruritic rash } \\
\text { which led to study drug } \\
\text { discontinuation. }\end{array}$ \\
\hline [88] & 2014 & $\mathrm{RCT}$ & 3 months & 32 & $\begin{array}{l}\text { Overweight older } \\
\text { adults }\end{array}$ & $\begin{array}{l}300(\mathrm{MD}) \\
\text { or } 1000 \\
\text { (HD) }\end{array}$ & $\begin{array}{l}\text { Low rate of AEs in treatment } \\
\text { groups. Two (2) subjects in } \\
\text { HD group withdrew due to } \\
\text { GI adverse events. } \\
\text { Authors reported } \\
\text { non-dose-dependent changes } \\
\text { in liver function tests. }\end{array}$ \\
\hline [89] & 2014 & $\mathrm{RCT}$ & 2 months & 20 & $\begin{array}{l}\text { Overweight or } \\
\text { obese men with } \\
\text { NAFLD }\end{array}$ & 3000 & $\begin{array}{l}\text { Mild GI adverse events } \\
\text { occurred at a higher rate in } \\
\text { subjects on resveratrol. } \\
\text { Furthermore, AST and ALT } \\
\text { levels were significantly } \\
\text { increased. }\end{array}$ \\
\hline [90] & 2010 & $\begin{array}{c}\text { Dose } \\
\text { escalation }\end{array}$ & 1 month & 40 & Healthy volunteers & $500-5000$ & $\begin{array}{l}\text { Adverse GI events were most } \\
\text { commonly reported at the } \\
2500 \mathrm{mg} \text { and } 5000 \mathrm{mg} \text { dose } \\
\text { levels, and these included } \\
\text { nausea, flatulence, abdominal } \\
\text { discomfort, and diarrhea. } \\
\text { The study also noted elevated } \\
\text { bilirubin levels at the } 500 \text { and } \\
1000 \mathrm{mg} \text { dose levels. }\end{array}$ \\
\hline
\end{tabular}

AE: adverse event; ALT: alanine aminotransferase; AST: aspartate aminotransferase; GI: gastrointestinal; HD: high dose; LD: low dose; MD: moderate dose; NAFLD: non-alcoholic fatty liver disease; RCT: randomized controlled trial.

Resveratrol intake may also lead to a dose-dependent alteration in liver enzymes, particularly AST/ALT and bilirubin. Reduction in liver enzymes was reported more often with doses less than $1 \mathrm{~g}$, while elevations were reported most commonly with doses greater than $1 \mathrm{~g}$. The most significant liver enzyme abnormality occurred in a subject receiving $5 \mathrm{~g}$ of resveratrol leading to cholestatic liver dysfunction [86]. The subject subsequently discontinued, and liver function returned to normal 8 weeks after drug discontinuation.

Other AEs reported with resveratrol include rash and weight loss. In one study administering

$2 \mathrm{~g}$ resveratrol vs. placebo, rash resolved after cessation of resveratrol [87]. Rash did not appear related to dose level. One study reviewed reported weight loss with resveratrol [85]. In this study, 
subjects were included if they were on stable medications for Alzheimer's disease management for 4 months. One of the medications used, rivastigmine, has been reported to cause weight loss [91]. For example, rates of weight loss, diarrhea, and nausea for rivastigmine according to the package insert are $18-26 \%, 7-19 \%$, and $29-47 \%$, respectively [91]. However, these subjects were noted to be stabilized on their respective medications and the article did not identify the specific medications that subjects were on. Of note, the adverse event of weight loss has been previously reported in some animal studies of resveratrol [92-94].

Only three studies reviewed reported no adverse events; in these studies, resveratrol was administered at doses significantly less than $1000 \mathrm{mg}$.

In conclusion, resveratrol is associated with important health benefits as well as dose-related adverse events (i.e., gastrointestinal side effects and alterations in liver enzymes). These were more prevalent at doses greater than $1000 \mathrm{mg}$ per day. Given that the SIL formulation contains 50 to $250 \mathrm{mg}$ resveratrol per day, we anticipate minimal to no adverse events at this dose range. Furthermore, although not listed on the UNPA list, resveratrol is currently marketed in a number of products that can be purchased online as well as in stores.

\section{Menaquinone-7}

Vitamin K, shown in Figure 4, is a fat-soluble vitamin that comprises vitamin K1, also known as the phylloquinones and vitamin $\mathrm{K} 2$, the menaquinones. Vitamin $\mathrm{K}$ compounds possess a common methylated naphthoquinone ring structure, but are distinguished by the length and degree of saturation of the aliphatic side chain at the number 3 position $[96,97]$. Menaquinones are abbreviated MK-n, with $n$ signifying the number of repeating 5 carbon (prenyl) units [97]. Hence, the longer the side chain, the greater the $\mathrm{n}$. Vitamin $\mathrm{K}$ is naturally occurring in plants as phylloquinones, while menaquinones are derived from anaerobic bacterial synthesis in the human gastrointestinal tract $[97,98]$. Of the 14 known menaquinone compounds (MK-1 to MK-14), MK-4 and MK-7 are the most common [97]. While phylloquinone occurs ubiquitously in green leafy vegetables and some legumes and vegetable oils [97], menaquinones can be derived from meats, eggs, curd, cheese, and fermented soybean, which is a rich source of MK-7 [97-99]. Vitamin K is a key cofactor for the enzyme y-glutamyl carboxylase, a process necessary for the activation of hepatic clotting factors [100] - particularly factors II (prothrombin), VII, IX, and X (collectively known as vitamin-K-dependent clotting factors) and proteins $C$ and $S$, which are endogenous anticoagulants [98]. It is also crucial for production of osteocalcin (OC) in the bone and matrix Gla protein (MGP) in the cartilage and vessel wall. 


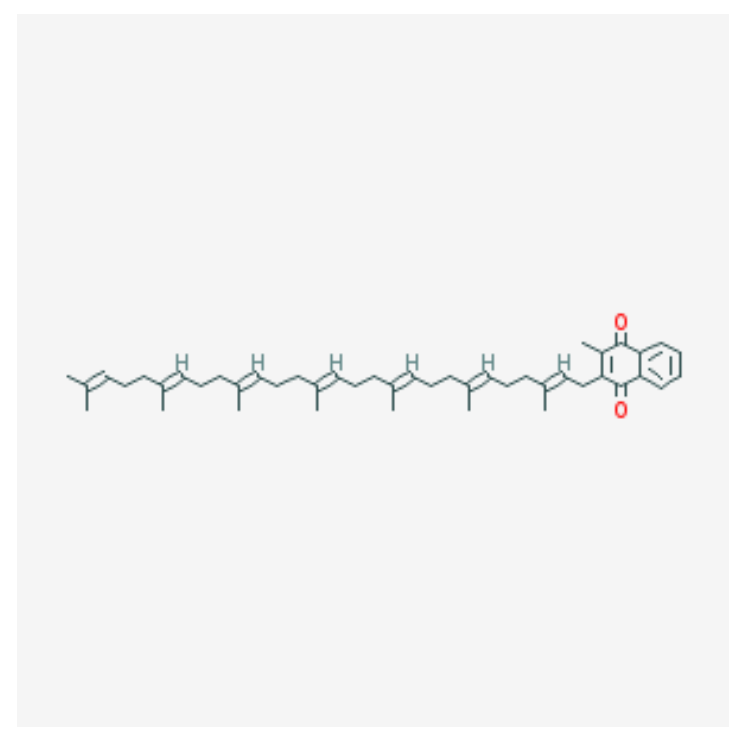

$2124-57-4$

Figure 4. Chemical structure of menaquinone-7 with its CASRN [95].

MGP is necessary for the inhibition of calcification, as was demonstrated by Luo et al. [101]. In that study, MGP-deficient mice were observed to die within two months due to rupture in the abdominal aorta secondary to calcification at multiple sites. In addition, animal and human studies illustrate the association between warfarin - an anticoagulant whose mechanism of action involves inhibition of vitamin-K-dependent clotting factors-and the development of arterial calcification [102-104]. This is likely due to the inactivation of MGP, a necessary endogenous calcification inhibitor [105].

The SIL formulation includes vitamin K2 as menaquinone-7 (MK-7) due to studies showing that a diet high in longer-chain menaquinones is associated with decreased risk of coronary heart disease $[100,104]$. Additionally, a study by Buithuis et al. showed that longer-chain K2 vitamins such as MK-7 are the preferred cofactors for vascular vitamin-K-dependent carboxylase [106]. Further, Schurgers et al. illustrated in healthy volunteers that MK-7 significantly induced the carboxylation of OC and MGP while no such effects were observed for vitamin K1 [107]. A hypothesis for the evaluation of MK-7 for the mitigation of vascular calcification is its longer rate of clearance, as a result of increased lipophilicity and enhanced degree of y-carboxylation [108]. Consequently, a randomized double-blind placebo controlled clinical study evaluating the effects of MK-7 supplementation on the progression of coronary artery calcification is underway.

The absorption of menaquinone from the small intestine was initially thought to be limited due to its hydrophobicity and the lack of bile salts for solubilization and absorption [97]. However, menaquinone has been shown to contribute significantly to hepatic vitamin $\mathrm{K}$ content in a similar ratio as phylloquinones. A study of MK-7 in healthy female volunteers administered a single $420-\mu \mathrm{g}$ dose showed that MK-7 was absorbed to a greater extent and had a longer half-life than the same dose of MK-4 [109]. In another study which compared the absorption of vitamin K1 and MK-7, the bioavailability of MK-7 was found to be 2.5 times that of vitamin K1 expressed as area under the plasma concentration time curve (AUC) over $24 \mathrm{~h}$ [107]. In this study, MK-7 remained detectable for at least 4 days.

\section{Safety Profile from Clinical Studies on Menaquinone-7}

It appears that the main safety concern with the use of MK-7 as reviewed in Table 4, is its effect on coagulation parameters, particularly in patients on concomitant anticoagulant-specifically coumarin derivatives. In the study by Theuwissen et al., no coagulation-related AEs were reported in healthy subjects in the range of doses evaluated [110]. The authors surmised that this was to 
be expected given that the population studied included healthy subjects not on thromboembolic prophylaxis with coumarin derivatives. Conversely, in another study where healthy subjects were treated with acenocoumarol (an anticoagulant coumarin derivative), MK-7 was a more potent inhibitor of anticoagulation when compared to vitamin K1 [107]. A dose of $130 \mu \mathrm{g} / \mathrm{d}$ of MK-7 decreased the international normalized ratio (INR) from 2.0 to 1.5 while a dose of $315 \mu \mathrm{g} / \mathrm{d}$ of vitamin $\mathrm{K} 1$ was necessary to achieve a comparable decrease in INR. Based on this observation, the authors proposed an upper safety limit of $50 \mu \mathrm{g} / \mathrm{d}$ of long-chain menaquinone for patients on oral anticoagulant treatment.

Table 4. Summary of Safety Profile of Menaquinone-7.

\begin{tabular}{|c|c|c|c|c|c|c|c|}
\hline Reference & Year & $\begin{array}{l}\text { Study } \\
\text { Design }\end{array}$ & $\begin{array}{l}\text { Duration } \\
\text { (months) }\end{array}$ & $\mathbf{N}$ & Study Population & $\begin{array}{l}\text { Dose } \\
(\mathrm{mcg})\end{array}$ & Safety Result \\
\hline [110] & 2012 & $\mathrm{RCT}$ & 3 & 42 & Healthy volunteers & $10-360$ & $\begin{array}{l}\text { No AEs on thrombin } \\
\text { generation observed. }\end{array}$ \\
\hline [111] & 2017 & $\begin{array}{l}\text { Single-arm } \\
\text { trial }\end{array}$ & 2 & 60 & Renal transplant & 360 & $\begin{array}{l}\text { AEs reported during } \\
\text { treatment included increase } \\
\text { serum creatinine (unrelated } \\
\text { to MK-7) and mild GI } \\
\text { symptoms such as nausea, } \\
\text { vomiting, diarrhea, and } \\
\text { constipation. }\end{array}$ \\
\hline [112] & 2010 & $\mathrm{RCT}$ & 12 & 334 & $\begin{array}{c}\text { Early } \\
\text { postmenopausal } \\
\text { women }\end{array}$ & 360 & $\begin{array}{l}\text { No significant AEs were } \\
\text { reported. Example of AEs in } \\
\text { the MK-7 group included } \\
\text { increased nocturnal hot } \\
\text { flashes, abdominal pain, and } \\
\text { increased palpitations. }\end{array}$ \\
\hline [113] & 2014 & $\mathrm{RCT}$ & 2 & 200 & $\begin{array}{l}\text { Hemodialysis } \\
\text { patients }\end{array}$ & $360-1080$ & $\begin{array}{l}\text { Eleven percent ( } 11 \% \text { ) of } \\
\text { subjects reported mild GI } \\
\text { adverse events. Five (5) } \\
\text { deaths occurred in this study; } \\
\text { one (1) occurred in the } 360 \mu \mathrm{g} \\
\text { group, two (2) in the } 720 \mu \mathrm{g} \\
\text { and } 1080 \mu \mathrm{g} \text { groups. Four (4) } \\
\text { deaths were due to CV event } \\
\text { in patients with documented } \\
\text { CVD and the other was due } \\
\text { to opportunistic infection in } \\
\text { an immunocompromised } \\
\text { patient. These were thought } \\
\text { to be related to the } \\
\text { underlying comorbidity. }\end{array}$ \\
\hline
\end{tabular}

AE: adverse event; CV: cardiovascular; CVD: cardiovascular disease; GI: gastrointestinal; MK-7: menaquinone-7;

RCT: randomized controlled trial.

The interaction between MK-7 and coumarin anticoagulants is manageable in clinical practice given that patients on warfarin are typically counseled to maintain a consistent intake of a vitamin-K-containing diet, and the dose of warfarin can be adjusted to the patient's desired vitamin $\mathrm{K}$ intake [114].

Overall, MK-7 is expected to be safe in a healthy patient population not anticipated to be on concomitant anticoagulation. Studies reporting adverse events with use of MK-7 had enrolled patient populations with underlying renal dysfunction. In addition, the concern regarding the alteration of coagulation parameters in patients on coumarin derivatives is manageable since these patients are being closely monitored in anticoagulation clinics to ensure therapeutic INR. Finally, the SIL formulation contains MK-7 at doses ranging from 30 to $360 \mu \mathrm{g}$, which as reported above are reasonably expected to be safe.

\section{Magnesium}

Magnesium is an essential mineral for a variety of life-sustaining reactions in the body [115]. It is a cofactor for a number of enzymatic reactions which modulate protein synthesis, muscle and nerve function, blood glucose, blood pressure control, etc. It can be derived from many dietary 
sources. Examples include nuts (almonds), whole grains, green leafy vegetables (e.g., spinach), meats, and dairy [116]. Although magnesium is ubiquitous in the human diet, it can also be derived from dietary supplements and medications such as antacids and laxatives [115].

For medications and/or dietary supplements, magnesium is delivered via different salts with varied bioavailability. Some examples are magnesium oxide, magnesium chloride, and magnesium citrate [115]. A study of magnesium bioavailability from different salts in magnesium-deficient rats showed improved absorption of magnesium from organic salt as compared to inorganic salts [117]. Studies in humans support the improved bioavailability of magnesium when administered as aspartate, lactate, citrate, and chloride as compared to oxide and sulfate [115].

With respect to cardiovascular health, magnesium lowers diastolic blood pressure (albeit to a small extent), modulates vascular tone, and is inversely associated with coronary artery calcification and CV risk factors [118-121]. When deficient, it is associated with impaired electrical conduction in the cardiac muscle, leading to arrhythmias [122].

Adverse effects of magnesium typically occur from non-food sources used for pharmacologic purposes [122]. The most commonly reported AE from magnesium is diarrhea, hence its use as an osmotic laxative in the form of magnesium hydroxide. In this study, the dose observed to be needed for its laxative effect was $500 \mathrm{mg}$ elemental magnesium which is considerably higher than the recommended dietary allowance (RDA), which ranges from 30-420 mg depending on the gender and age range [115]. When it occurs, diarrhea may be accompanied by nausea and abdominal cramping [122].

Magnesium is an essential mineral, and is currently used in a number of pharmacological products either over the counter or via prescription. The most common AE experienced from magnesium is diarrhea, which as mentioned above is expected to occur in a formulation requiring $500 \mathrm{mg}$ elemental magnesium. In the SIL formulation, the dose of magnesium per capsule ranges from 50 to $300 \mathrm{mg}$, which is below the RDA, and as such is expected to be safe.

\section{Safety Profile in Clinical Studies on Combination Ingredients}

A clinical study designed to evaluate the safety and efficacy of the SIL formulation is ongoing. Thus far, under the supervision of an integrative medicine physician, 25 subjects with underlying comorbid conditions such as hyperlipidemia and hypertension have taken the SIL formulation. No adverse effects have been reported after 3 months on the SIL formulation. Enrollment remains ongoing and the study will continue for 9 months. This will provide additional safety data on the use of the SIL formulation.

While clinical studies evaluating the safety of the SIL formulation are limited, there are a couple of studies evaluating the combination of one or two of the ingredients together and/or with other ingredients for a number of disease indications.

Torella et al. (2016) assessed a combination of hyaluronic acid, chondroitin sulfate, curcumin, and quercetin for the prevention of recurrent urinary tract infections in postmenopausal women [123]. In this study, the combination was administered orally, and no adverse events were reported. However, the doses evaluated were not specified.

Curcumin (480 mg) and quercetin $(20 \mathrm{mg})$ were administered in combination to five (5) patients with familial adenomatous polyposis three times a day for 9 months to evaluate the effect on adenoma regression [124]. Adverse events reported were mild and included nausea, sour taste after pill ingestion, and loose stools.

A formulation (MPX) containing ellagic acid, quercetin, and resveratrol was evaluated in a Phase I dose escalation study of patients with biochemically recurrent prostate cancer. Patients were administered one (1) $500 \mathrm{mg}$ MPX capsule daily for more than 12 months [125]. Each capsule in the formulation contained $1.2 \mathrm{mg}$ ellagic acid, $9.2 \mu \mathrm{g}$ quercetin, and $4.4 \mu \mathrm{g}$ trans-resveratrol. Treatment was initiated at $500 \mathrm{mg} /$ day to a maximum of $4000 \mathrm{mg} /$ day. Treatment-related AEs were mild and included mostly GI AEs in 36\% (5/14) of patients. Of these, 4 were in the highest dose group. Seven (7) patients 
withdrew from study for non-treatment related reasons. The remaining seven remained on the study drug for 21-30+ months.

A pharmacokinetic study examined the steady-state pharmacokinetics and tolerability of trans-resveratrol $2000 \mathrm{mg}$ twice daily with: i) a standard breakfast, ii) a high-fat breakfast, iii) quercetin $500 \mathrm{mg}$ twice daily, and iv) 5\% alcohol in eight (8) healthy subjects [126]. Adverse events reported were mild and included diarrhea and transient rash. These are consistent with earlier studies of resveratrol at doses greater than $1 \mathrm{~g}$. Furthermore, quercetin did not alter the pharmacokinetics of resveratrol.

The adverse event patterns reported with these combination studies are consistent with those reported when these ingredients are used individually. They are generally mild and involve the gastrointestinal tract. Supporting the suitability of the use of these ingredients is the fact that some are currently being marketed as single ingredients or in combination, and are available in stores or for online purchase at doses at or well above that in the SIL formulation.

\section{Drug Interactions}

Based on the literature reviewed above, the evidence suggests that each ingredient in the SIL formulation is reasonably expected to be safe at the proposed dose when used singly or in combination. Nonetheless, safety concerns might arise because of the potential for drug interactions when these ingredients are combined based on the purported in vitro activity of some of the ingredients on drug metabolism pathways.

For example, curcuminoids inhibit the activity of a number of cytochrome P450 enzymes (CYPs) as well as p-glycoprotein [127]. Notable CYP enzymes inhibited by curcuminoids include 2C9, 2C19, 2D6, and 3A4. Respectively, these CYP enzymes are known for metabolizing the drugs warfarin, clopidogrel, fluoxetine, and azole antifungals. In the case of warfarin, an anticoagulant with a narrow therapeutic index, there is a theoretical risk of increased toxicity of warfarin leading to increased bleeding. Similarly, in vitro studies report the inhibitory activity of curcumin on p-glycoprotein-an efflux pump responsible for maintaining low cellular concentrations of certain classes of drugs such as chemotherapeutic and immunosuppressant drugs [128,129]. Consequently, there is a potential for elevated systemic levels of p-glycoprotein substrates and ensuing toxicity when administered concomitantly with curcumin. A recent review details the theoretical pharmacokinetic interactions of curcumin [127].

Curcumin possesses many theoretical pharmacologic activities that might potentiate the effect of other prescription and over-the-counter (OTC) drugs with similar activities. For example, curcumin is believed to possess antiplatelet activity due to its ability to inhibit arachidonic acid incorporation into platelets [130] as well as cyclooxygenase (COX) inhibition [131,132]. When administered with other antiplatelet agents such as aspirin, which is readily available over the counter, there may be a theoretical increased risk of bleeding. Therefore, users of such dietary supplements should be counseled on the potential risk of the drug interaction. A similar interaction might be expected when used in conjunction with other NSAIDs due to curcumin's purported anticoagulant activity [133].

Curcumin has also been reported to exhibit antidepressant activity in a randomized controlled trial of patients with major depressive disorder [134]. In this study, curcumin was administered at a dose of $1000 \mathrm{mg}$ per day for 6 weeks. The authors expressed a concern for the theoretical risk of serotonin syndrome due to the pharmacodynamic interaction between fluoxetine and curcumin, although no signs were observed in the study.

Like curcumin, resveratrol inhibits similar CYP enzymes. A study conducted in 42 healthy volunteers found that resveratrol inhibited CYP 3A4, 2D6, and 2C9 and induced 1A2 after administering $1 \mathrm{~g}$ daily for 4 weeks [84]. The authors reported a concern that this could lead to increased toxicity or altered drug efficacy. As is the case with curcumin, there is a theoretical risk of interaction with drugs with narrow indices such as amiodarone and warfarin which are commonly used in patients with CVD [86]. Finally, resveratrol possesses blood pressure lowering and anticoagulant effects, 
which may lead to additive drug interactions when used concomitantly with drugs possessing similar pharmacological activity [74].

Unlike curcumin's inhibitory activity on p-glycoprotein, in vitro studies suggest that quercetin induces the activity of p-glycoprotein [135] and CYP3A metabolism of midazolam with repeated exposure in Chinese subjects [136]. Quercetin was also shown to inhibit activity on OATP1B1-mediated transport of pravastatin in Chinese subjects [137].

Overall, the potential for drug-drug interaction is expected to be low because the quantities of curcumin, resveratrol, quercetin, and other ingredients in each dose of SIL are low and within the levels in currently marketed single and combination products.

\section{Conclusions}

Given the increase in CVD burden due to an ever-growing and aging population, the SIL formulation was strategically designed to modulate CVD triggers with the goal of maintaining good cardiovascular health in a relatively healthy population. The SIL formulation consists of select polyphenols (curcumin 30-150 mg, quercetin $20-100 \mathrm{mg}$, resveratrol 50-250 mg), magnesium 50-300 mg, and menaquinone-7 30-360 $\mu \mathrm{g}$. These ingredients are currently available in marketed products at doses well above the proposed amounts in the SIL formulation.

As illustrated above, mild gastrointestinal AEs were most commonly reported for the majority of the ingredients. For resveratrol in particular, AEs appeared to be dose dependent with gastrointestinal AEs and alterations in liver enzymes occurred more often at doses above $1 \mathrm{~g}$. Studies on curcumin and quercetin generally reported minimal or no adverse events. For menaquinone-7, the primary concern is alteration of coagulation parameters, which could lead to significant adverse events in patients on concomitant anticoagulants with coumarin derivatives. However, this is not expected to be an issue in otherwise healthy patient populations. Finally, magnesium is widely used over the counter and as a prescription drug, with diarrhea as its well-known adverse event.

Another aspect of this review was a literature evaluation of the potential for drug interactions. The overall conclusion was that although there is a theoretical basis for drug interactions based on the pharmacological profile of these ingredients, the potential for drug interaction is negligible given the low quantities of each ingredient within the SIL formulation.

While the preponderance of clinical trials reviewed in this article support the overall safety of the bioactives within the SIL formulation, a major limitation of this review is the extrapolation of the data on the safety of the individual bioactives to the SIL formulation as a whole. Future studies evaluating safety of the SIL formulation could provide additional insight. Nonetheless, when evaluating the safety of the SIL formulation, it is important to note that the amounts of the bioactives in the SIL formulation are lower than i) the doses evaluated in the clinical trials reviewed and ii) the amount present in currently marketed products containing the same ingredients either singly or in combination. In light of these, we conclude that the combination of ingredients in the SIL formulation is reasonably expected to be safe. Finally, as with any other dietary supplements, the use of the SIL formulation is not expected to replace a healthy diet (e.g., the Mediterranean diet) and the maintenance of cardiac-health-promoting behaviors.

Author Contributions: F.O.A. and W.S. conceived, designed and guided the development of the manuscript. M.A.-W. wrote the manuscript and coordinated review.

Funding: This research received no external funding.

Conflicts of Interest: Mayowa Agbaje-Williams is a paid clinical scientist consultant for Summit Innovation Labs. The other authors declare no conflicts of interest. 


\section{References}

1. Roth, G.A.; Huffman, M.D.; Moran, A.E.; Feigin, V.; Mensah, G.A.; Naghavi, M.; Murray, C.J. Global and regional patterns in cardiovascular mortality from 1990 to 2013. Circulation 2015, 132, 1667-1678. [CrossRef] [PubMed]

2. Sidney, S.; Quesenberry, C.P., Jr.; Jaffe, M.G.; Sorel, M.; Nguyen-Huynh, M.N.; Kushi, L.H.; Go, A.S.; Rana, J.S. Recent Trends in Cardiovascular Mortality in the United States and Public Health Goals. JAMA Cardiol. 2016, 1, 594-599. [CrossRef] [PubMed]

3. Centers for Disease Control, National Center for Health Statistics. Underlying Cause of Death 1999-2013 on CDC WONDER Online Database, Released 2015. Available online: https:/www.cdc.gov/heartdisease/facts. htm (accessed on 23 October 2017).

4. GBD 2013 Mortality and Causes of Death Collaborators. Global, regional, and national age-sex specific all-cause and cause-specific mortality for 240 causes of death, 1990-2013: A systematic analysis for the Global Burden of Disease Study 2013. Lancet 2015, 385, 117-171. [CrossRef]

5. Murray, C.J.; Vos, T.; Lozano, R.; Naghavi, M.; Flaxman, A.D.; Michaud, C.; Ezzati, M.; Shibuya, K.; Salomon, J.A.; Abdalla, S.; et al. Disability-adjusted life years (DALYs) for 291 diseases and injuries in 21 regions, 1990-2010: A systematic analysis for the Global Burden of Disease Study 2010. Lancet 2012, 380, 2197-2223. [CrossRef]

6. Ma, J.; Ward, E.M.; Siegel, R.L.; Jemal, A. Temporal Trends in Mortality in the United States, 1969-2013. JAMA 2015, 314, 1731-1739. [CrossRef]

7. Shah, P.K.; Falk, E. Pathophysiology of Myocardial Ischemia. In Cardiology E-Book, 3rd ed.; Crawford, M.H., DiMarco, J.P., Paulus, W.J., Eds.; Elsevier Health Sciences: Amsterdam, The Netherlands, 2009; pp. 243-253. ISBN 0723436444.

8. Hansson, G.K.; Libby, P. The immune response in atherosclerosis: A double-edged sword. Nat. Rev. Immunol. 2006, 6, 508-519. [CrossRef]

9. Scott, J. Pathophysiology and biochemistry of cardiovascular disease. Curr. Opin. Genet. Dev. 2004, 14, $271-279$. [CrossRef]

10. Mano, T.; Masuyama, T.; Yamamoto, K.; Naito, J.; Kondo, H.; Nagano, R.; Tanouchi, J.; Hori, M.; Inoue, M.; Kamada, T. Endothelial dysfunction in the early stage of atherosclerosis precedes appearance of intimal lesions assessable with intravascular ultrasound. Am. Heart J. 1996, 131, 231-238. [CrossRef]

11. Byon, C.H.; Javed, A.; Dai, Q.; Kappes, J.C.; Clemens, T.L.; Darley-Usmar, V.M.; McDonald, J.M.; Chen, Y. Oxidative Stress Induces Vascular Calcification through Modulation of the Osteogenic Transcription Factor Runx2 by AKT Signaling. J. Biol. Chem. 2008, 283, 15319-15327. [CrossRef]

12. Wang, T.J.; Larson, M.G.; Levy, D.; Benjamin, E.J.; Kupka, M.J.; Manning, W.J.; Clouse, M.E.; D'Agostino, R.B.; Wilson, P.W.; O'Donnell, C.J. C-Reactive Protein Is Associated With Subclinical Epicardial Coronary Calcification in Men and Women. Fram. Heart Study 2002, 106, 1189-1191. [CrossRef]

13. Doherty, T.M.; Asotra, K.; Fitzpatrick, L.A.; Qiao, J.H.; Wilkin, D.J.; Detrano, R.C.; Dunstan, C.R.; Shah, P.K.; Rajavashisth, T.B. Calcification in atherosclerosis: Bone biology and chronic inflammation at the arterial crossroads. Proc. Natl. Acad. Sci. USA 2003, 100, 11201-11206. [CrossRef] [PubMed]

14. Blacher, J.; Guerin, A.P.; Pannier, B.; Marchais, S.J.; London, G.M. Arterial calcifications, arterial stiffness, and cardiovascular risk in end-stage renal disease. Hypertension 2001, 38, 938-942. [CrossRef] [PubMed]

15. Khurana, S.; Venkataraman, K.; Hollingsworth, A.; Piche, M.; Tai, T.C. Polyphenols: Benefits to the cardiovascular system in health and in aging. Nutrients 2013, 5, 3779-3827. [CrossRef] [PubMed]

16. Estruch, R.; Ros, E.; Salas-Salvadó, J.; Covas, M.I.; Corella, D.; Arós, F.; Gómez-Gracia, E.; Ruiz-Gutiérrez, V.; Fiol, M.; Lapetra, J.; et al. Primary prevention of cardiovascular disease with a Mediterranean diet. N. Engl. J. Med. 2013, 368, 1279-1290. [CrossRef]

17. Manach, C.; Scalbert, A.; Morand, C.; Rémésy, C.; Jiménez, L. Polyphenols: Food sources and bioavailability. Am. J. Clin. Nutr. 2004, 79, 727-747. [CrossRef]

18. Crozier, A.; Lean, M.E.J.; McDonald, M.S.; Black, C. Quantitative analysis of the flavonoid content of commercial tomatoes, onions, lettuce, and celery. J. Agric. Food Chem. 1997, 45, 590-595. [CrossRef]

19. Tangney, C.C.; Rasmussen, H.E. Polyphenols, inflammation, and cardiovascular disease. Curr. Atheroscler. Rep. 2013, 15, 324. [CrossRef]

20. Kumar, S.; Pandey, A.K. Chemistry and biological activities of flavonoids: An overview. Sci. World J. 2013, 162750. [CrossRef] 
21. Fitó, M.; Guxens, M.; Corella, D.; Sáez, G.; Estruch, R.; de la Torre, R.; Francés, F.; Cabezas, C.; López-Sabater Mdel, C.; Marrugat, J.; et al. Effect of a traditional Mediterranean diet on lipoprotein oxidation: A randomized controlled trial. Arch. Intern. Med. 2007, 167, 1195-1203. [CrossRef]

22. National Center for Biotechnology Information. PubChem Compound Database; CID=969516. Available online: https://pubchem.ncbi.nlm.nih.gov/compound/969516 (accessed on 16 October 2017).

23. Burgos-Morón, E.; Calderón-Montaño, J.M.; Salvador, J.; Robles, A.; López-Lázaro, M. The dark side of curcumin. Int. J. Cancer 2010, 126, 1771-1775. [CrossRef]

24. Aggarwal, B.B.; Sundaram, C.; Malani, N.; Ichikawa, H. Curcumin: The Indian Solid Gold. In The Molecular Targets and Therapeutic Uses of Curcumin in Health and Disease; Aggarwal, B.B., Surh, Y.J., Shishodia, S., Eds.; Springer: Boston, MA, USA, 2007; Volume 595, pp. 1-75. ISBN 978-0-387-46401-5.

25. EFSA Panel on Food Additives and Nutrient Sources added to Food (ANS). Scientific Opinion on the reevaluation of curcumin (E 100) as a food additive. EFSA J. 2010, 8, 1679.

26. Madhu, K.; Chanda, K.; Saji, M.J. Safety and efficacy of Curcuma longa extract in the treatment of painful knee osteoarthritis: A randomized placebo-controlled trial. Inflammopharmacology 2013, 21, 129-136. [CrossRef]

27. Chandran, B.; Goel, A. A randomized, pilot study to assess the efficacy and safety of curcumin in patients with active rheumatoid arthritis. Phytother. Res. 2012, 26, 1719-1725. [CrossRef] [PubMed]

28. Hanai, H.; Iida, T.; Takeuchi, K.; Watanabe, F.; Maruyama, Y.; Andoh, A.; Tsujikawa, T.; Fujiyama, Y.; Mitsuyama, K.; Sata, M.; et al. Curcumin maintenance therapy for ulcerative colitis: Randomized, multicenter, double-blind, placebo-controlled trial. Clin. Gastroenterol. Hepatol. 2006, 4, 1502-1506. [CrossRef] [PubMed]

29. Gupta, S.C.; Patchva, S.; Aggarwal, B.B. Therapeutic Roles of Curcumin: Lessons Learned from Clinical Trials. AAPS J. 2013, 15, 195-218. [CrossRef]

30. Sharma, R.A.; McLelland, H.R.; Hill, K.A.; Ireson, C.R.; Euden, S.A.; Manson, M.M.; Pirmohamed, M.; Marnett, L.J.; Gescher, A.J.; Steward, W.P. Pharmacodynamic and pharmacokinetic study of oral Curcuma extract in patients with colorectal cancer. Clin. Cancer Res. 2001, 7, 1894-1900. [PubMed]

31. Chuengsamarn, S.; Rattanamongkolgul, S.; Luechapudiporn, R.; Phisalaphong, C.; Jirawatnotai, S. Curcumin extract for prevention of type 2 diabetes. Diabetes Care 2012, 35, 2121-2127. [CrossRef]

32. Mirzabeigi, P.; Mohammadpour, A.H.; Salarifar, M.; Gholami, K.; Mojtahedzadeh, M.; Javadi, M.R. The Effect of Curcumin on some of Traditional and Non-traditional Cardiovascular Risk Factors: A Pilot Randomized, Double-blind, Placebo-controlled Trial. Iran. J. Pharm Res. 2015, 14, 479-486.

33. Sasaki, H.; Sunagawa, Y.; Takahashi, K.; Imaizumi, A.; Fukuda, H.; Hashimoto, T.; Wada, H.; Katanasaka, Y.; Kakeya, H.; Fujita, M.; et al. Innovative preparation of curcumin for improved oral bioavailability. Biol. Pharm. Bull. 2011, 34, 660-665. [CrossRef]

34. Naksuriya, O.; Okonogi, S.; Schiffelers, R.M.; Hennink, W.E. Curcumin nanoformulations: A review of pharmaceutical properties and preclinical studies and clinical data related to cancer treatment. Biomaterials 2014, 35, 3365-3383. [CrossRef]

35. Cuomo, J.; Appendino, G.; Dern, A.S.; Schneider, E.; McKinnon, T.P.; Brown, M.J.; Togni, S.; Dixon, B.M. Comparative absorption of a standardized curcuminoid mixture and its lecithin formulation. J. Nat. Prod. 2011, 74, 664-669. [CrossRef]

36. Shoba, G.; Joy, D.; Joseph, T.; Majeed, M.; Rajendran, R.; Srinivas, P.S. Influence of piperine on the pharmacokinetics of curcumin in animals and human volunteers. Planta Med. 1998, 64, 353-356. [CrossRef] [PubMed]

37. Riva, A.; Togni, S.; Giacomelli, L.; Franceschi, F.; Eggenhoffner, R.; Feragalli, B.; Belcaro, G.; Cacchio, M.; Shu, H.; Dugall, M. Effects of a curcumin-based supplementation in asymptomatic subjects with low bone density: A preliminary 24-week supplement study. Eur. Rev. Med. Pharm. Sci. 2017, 21, 1684-1689.

38. Panahi, Y.; Rahimnia, A.R.; Sharafi, M.; Alishiri, G.; Saburi, A.; Sahebkar, A. Curcuminoid treatment for knee osteoarthritis: A randomized double-blind placebo-controlled trial. Phytother. Res. 2014, 28, 1625-1631. [CrossRef] [PubMed]

39. Suskind, D.L.; Wahbeh, G.; Burpee, T.; Cohen, M.; Christie, D.; Weber, W. Tolerability of curcumin in pediatric inflammatory bowel disease: A forced-dose titration study. J. Pediatr. Gastroenterol. Nutr. 2013, 56, 277-279. [CrossRef] [PubMed]

40. Cheng, A.L.; Hsu, C.H.; Lin, J.K.; Hsu, M.M.; Ho, Y.F.; Shen, T.S.; Ko, J.Y.; Lin, J.T.; Lin, B.R.; Ming-Shiang, W. Phase I clinical trial of curcumin, a chemopreventive agent, in patients with high-risk or pre-malignant lesions. Anticancer Res. 2001, 21, 2895-2900. 
41. Lao, C.D.; Ruffin, M.T., IV; Normolle, D.; Heath, D.D.; Murray, S.I.; Bailey, J.M.; Boggs, M.E.; Crowell, J.; Rock, C.L.; Brenner, D.E. Dose escalation of a curcuminoid formulation. BMC Complement. Altern. Med. 2006, 6, 10. [CrossRef]

42. National Center for Biotechnology Information. PubChem Compound Database. CID = 5280343. Available online: https://pubchem.ncbi.nlm.nih.gov/compound/5280343\#section=Top (accessed on 16 October 2017).

43. National Center for Biotechnology Information. PubChem Compound Database. CID = 5280804. Available online: https://pubchem.ncbi.nlm.nih.gov/compound/Isoquercitrin\#section=Top (accessed on 16 October 2017).

44. National Center for Biotechnology Information. PubChem Compound Database; CID = 5280805. Available online: https://pubchem.ncbi.nlm.nih.gov/compound/5280805\#section=Top (accessed on 16 October 2017).

45. Murota, K.; Matsuda, N.; Kashino, Y.; Fujikura, Y.; Nakamura, T.; Kato, Y.; Shimizu, R.; Okuyama, S.; Tanaka, H.; Koda, T.; et al. alpha-Oligoglucosylation of a sugar moiety enhances the bioavailability of quercetin glucosides in humans. Arch. Biochem. Biophys. 2010, 501, 91-97. [CrossRef] [PubMed]

46. Hrelia, S.; Angeloni, S. Quercetin and its metabolites in heart health. In Bioactive Foods as Dietary Interventions for Cardiovascular Disease, 1st ed.; Watson, R.R., Preedy, V.R., Eds.; Academic Press: San Diego, CA, USA, 2013; pp. 217-228. ISBN 0123964857.

47. Lesser, S.; Wolffram, S. Oral bioavailability of the flavonol quercetin-A review. Curr. Top. Nutraceutical Res. 2006, 4, 239-256.

48. Makino, T.; Shimizu, R.; Kanemaru, M.; Suzuki, Y.; Moriwaki, M.; Mizukami, H. Enzymatically modified isoquercitrin, alpha-oligoglucosyl quercetin 3-O-glucoside, is absorbed more easily than other quercetin glycosides or aglycone after oral administration in rats. Biol. Pharm. Bull. 2009, 32, 2034-2040. [CrossRef]

49. Russo, M.; Spagnuolo, C.; Tedesco, I.; Bilotto, S.; Russo, G.L. The flavonoid quercetin in disease prevention and therapy: Facts and fancies. Biochem. Pharm. 2012, 83, 6-15. [CrossRef] [PubMed]

50. Cai, H.; Harrison, D.G. Endothelial dysfunction in cardiovascular diseases: The role of oxidant stress. Circ. Res. 2000, 87, 840-844. [CrossRef] [PubMed]

51. Badimon, L.; Padró, T.; Vilahur, G. Atherosclerosis, platelets and thrombosis in acute ischaemic heart disease. Eur. Heart J. Acute Cardiovasc. Care 2012, 1, 60-74. [CrossRef] [PubMed]

52. Loke, W.M.; Proudfoot, J.M.; Hodgson, J.M.; McKinley, A.J.; Hime, N.; Magat, M.; Stocker, R.; Croft, K.D. Specific dietary polyphenols attenuate atherosclerosis in apolipoprotein E-knockout mice by alleviating inflammation and endothelial dysfunction. Arter. Thromb. Vasc. Biol. 2010, 30, 749-757. [CrossRef] [PubMed]

53. Beazley, K.E.; Eghtesad, S.; Nurminskaya, M.V. Quercetin attenuates warfarin-induced vascular calcification in vitro independently from matrix Gla protein. J. Biol. Chem. 2013, 288, 2632-2640. [CrossRef] [PubMed]

54. Aukrust, P.; Halvorsen, B.; Ueland, T.; Michelsen, A.E.; Skjelland, M.; Gullestad, L.; Yndestad, A.; Otterdal, K. Activated platelets and atherosclerosis. Expert Rev. Cardiovasc. 2010, 8, 1297-1307. [CrossRef] [PubMed]

55. Hollman, P.C.; van Trijp, J.M.; Buysman, M.N.; van der Gaag, M.S.; Mengelers, M.J.; de Vries, J.H.; Katan, M.B. Relative bioavailability of the antioxidant flavonoid quercetin from various foods in man. FEBS Lett. 1997, 418, 152-156. [CrossRef]

56. Harwood, M.; Danielewska-Nikiel, B.; Borzelleca, J.F.; Flamm, G.W.; Williams, G.M.; Lines, T.C. A critical review of the data related to the safety of quercetin and lack of evidence of in vivo toxicity, including lack of genotoxic/carcinogenic properties. Food Chem. Toxicol. 2007, 45, 2179-2205. [CrossRef]

57. Hollman, P.C.; de Vries, J.H.; van Leeuwen, S.D.; Mengelers, M.J.; Katan, M.B. Absorption of dietary quercetin glycosides and quercetin in healthy ileostomy volunteers. Am. J. Clin. Nutr. 1995, 62, 1276-1282. [CrossRef]

58. Soleas, G.J.; Yan, J.; Goldberg, D.M. Ultrasensitive assay for three polyphenols (catechin, quercetin and resveratrol) and their conjugates in biological fluids utilizing gas chromatography with mass selective detection. J. Chromatogr. B Biomed. Sci. Appl. 2001, 757, 161-172. [CrossRef]

59. Knab, A.M.; Shanely, R.A.; Henson, D.A.; Jin, F.; Heinz, S.A.; Austin, M.D.; Nieman, D.C. Influence of quercetin supplementation on disease risk factors in community-dwelling adults. J. Am. Diet. Assoc. 2011, 111, 542-549. [CrossRef] [PubMed]

60. Edwards, R.L.; Lyon, T.; Litwin, S.E.; Rabovsky, A.; Symons, J.D.; Jalili, T. Quercetin reduces blood pressure in hypertensive subjects. J. Nutr. 2007, 137, 2405-2411. [CrossRef] [PubMed] 
61. Egert, S.; Bosy-Westphal, A.; Seiberl, J.; Kürbitz, C.; Settler, U.; Plachta-Danielzik, S.; Wagner, A.E.; Frank, J.; Schrezenmeir, J.; Rimbach, G.; et al. Quercetin reduces systolic blood pressure and plasma oxidised low-density lipoprotein concentrations in overweight subjects with a high-cardiovascular disease risk phenotype: A double-blinded, placebo-controlled cross-over study. Br. J. Nutr. 2009, 102, 1065-1074. [CrossRef] [PubMed]

62. Shi, Y.; Williamson, G. Quercetin lowers plasma uric acid in pre-hyperuricaemic males: A randomised, double-blinded, placebo-controlled, cross-over trial. Br. J. Nutr. 2016, 115, 800-806. [CrossRef] [PubMed]

63. Lu, N.T.; Crespi, C.M.; Liu, N.M.; Vu, J.Q.; Ahmadieh, Y.; Wu, S.; Lin, S.; McClune, A.; Durazo, F.; Saab, S.; et al. A Phase I Dose Escalation Study Demonstrates Quercetin Safety and Explores Potential for Bioflavonoid Antivirals in Patients with Chronic Hepatitis C. Phytother. Res. 2016, 30, 160-168. [CrossRef] [PubMed]

64. Lee, K.H.; Park, E.; Lee, H.J.; Kim, M.O.; Cha, Y.J.; Kim, J.M.; Lee, H.; Shin, M.J. Effects of daily quercetin-rich supplementation on cardiometabolic risks in male smokers. Nutr. Res. Pr. 2011, 5, 28-33. [CrossRef] [PubMed]

65. Egert, S.; Wolffram, S.; Bosy-Westphal, A.; Boesch-Saadatmandi, C.; Wagner, A.E.; Frank, J.; Rimbach, G.; Mueller, M.J. Daily quercetin supplementation dose-dependently increases plasma quercetin concentrations in healthy humans. J. Nutr. 2008, 138, 1615-1621. [CrossRef]

66. Ross, J.A.; Kasum, C.M. Dietary flavonoids: Bioavailability, metabolic effects, and safety. Annu. Rev. Nutr. 2002, 22, 19-34. [CrossRef]

67. Ministry of Health, Labor and Welfare (MLHW), Japan. List of Existing Food Additives. 1996. Available online: http://www.ffcr.or.jp/zaidan/FFCRHOME.nsf/pages/list-exst.add (accessed on 17 October 2017).

68. National Center for Biotechnology Information. PubChem Compound Database; CID = 445154. Available online: https://pubchem.ncbi.nlm.nih.gov/compound/445154\#section=Top (accessed on 17 October 2017).

69. Del Rio, D.; Rodriguez-Mateos, A.; Spencer, J.P.; Tognolini, M.; Borges, G.; Crozier, A. Dietary (poly)phenolics in human health: Structures, bioavailability, and evidence of protective effects against chronic diseases. Antioxid. Redox Signal 2013, 18, 1818-1892. [CrossRef]

70. Smoliga, J.M.; Baur, J.A.; Hausenblas, H.A. Resveratrol and health-A comprehensive review of human clinical trials. Mol. Nutr. Food Res. 2011, 55, 1129-1141. [CrossRef]

71. Chang, G.R.; Chen, P.L.; Hou, P.H.; Mao, F.C. Resveratrol protects against diet-induced atherosclerosis by reducing low-density lipoprotein cholesterol and inhibiting inflammation in apolipoprotein E-deficient mice. Iran. J. Basic Med. Sci. 2015, 18, 1063-1071. [PubMed]

72. Chachay, V.S.; Kirkpatrick, C.M.; Hickman, I.J.; Ferguson, M.; Prins, J.B.; Martin, J.H. Resveratrol—Pills to replace a healthy diet? Br. J. Clin. Pharm. 2011, 72, 27-38. [CrossRef]

73. Renaud, S.; de Lorgeril, M. Wine, alcohol, platelets, and the French paradox for coronary heart disease. Lancet 1992, 339, 1523-1526. [CrossRef]

74. Bonnefont-Rousselot, D. Resveratrol and Cardiovascular Diseases. Nutrients 2016, 8, 250. [CrossRef] [PubMed]

75. Berrougui, H.; Grenier, G.; Loued, S.; Drouin, G.; Khalil, A. A new insight into resveratrol as an atheroprotective compound: Inhibition of lipid peroxidation and enhancement of cholesterol efflux. Atherosclerosis 2009, 207, $420-427$. [CrossRef] [PubMed]

76. Frankel, E.N.; Waterhouse, A.L.; Kinsella, J.E. Inhibition of human LDL oxidation by resveratrol. Lancet 1993, 341, 1103-1104. [CrossRef]

77. Jeon, S.M.; Lee, S.A.; Choi, M.S. Antiobesity and vasoprotective effects of resveratrol in apoE-deficient mice. J. Med. Food 2014, 17, 310-316. [CrossRef]

78. Meng, C.; Liu, J.L.; Du, A.L. Cardioprotective effect of resveratrol on atherogenic diet-fed rats. Int. J. Clin. Exp. Pathol. 2014, 7, 7899-7906.

79. Chen, S.; Zhao, X.; Ran, L.; Wan, J.; Wang, X.; Qin, Y.; Shu, F.; Gao, Y.; Yuan, L.; Zhang, Q.; et al. Resveratrol improves insulin resistance, glucose and lipid metabolism in patients with non-alcoholic fatty liver disease: A randomized controlled trial. Dig. Liver Dis. 2015, 47, 226-232. [CrossRef]

80. Pace-Asciak, C.R.; Hahn, S.; Diamandis, E.P.; Soleas, G.; Goldberg, D.M. The red wine phenolics trans-resveratrol and quercetin block human platelet aggregation and eicosanoid synthesis: Implications for protection against coronary heart disease. Clin. Chim. Acta 1995, 235, 207-219. [CrossRef] 
81. Borriello, A.; Cucciolla, V.; Della Ragione, F.; Galletti, P. Dietary polyphenols: Focus on resveratrol, a promising agent in the prevention of cardiovascular diseases and control of glucose homeostasis. Nutr. Metab. Cardiovasc. Dis. 2010, 20, 618-625. [CrossRef] [PubMed]

82. Rimbaud, S.; Ruiz, M.; Piquereau, J.; Mateo, P.; Fortin, D.; Veksler, V.; Garnier, A.; Ventura-Clapier, R. Resveratrol improves survival, hemodynamics and energetics in a rat model of hypertension leading to heart failure. PLoS ONE 2011, 6, e26391. [CrossRef] [PubMed]

83. Goldberg, D.M.; Yan, J.; Soleas, G.J. Absorption of three wine-related polyphenols in three different matrices by healthy subjects. Clin. Biochem. 2003, 36, 79-87. [CrossRef]

84. Chow, H.H.; Garland, L.L.; Hsu, C.H.; Vining, D.R.; Chew, W.M.; Miller, J.A.; Perloff, M.; Crowell, J.A.; Alberts, D.S. Resveratrol modulates drug- and carcinogen-metabolizing enzymes in a healthy volunteer study. Cancer Prev. Res. 2010, 3, 1168-1175. [CrossRef] [PubMed]

85. Turner, R.S.; Thomas, R.G.; Craft, S.; van Dyck, C.H.; Mintzer, J.; Reynolds, B.A.; Brewer, J.B.; Rissman, R.A.; Raman, R.; Aisen, P.S. A randomized, double-blind, placebo-controlled trial of resveratrol for Alzheimer disease. Neurology 2015, 85, 1383-1391. [CrossRef] [PubMed]

86. Yiu, E.M.; Tai, G.; Peverill, R.E.; Lee, K.J.; Croft, K.D.; Mori, T.A.; Scheiber-Mojdehkar, B.; Sturm, B.; Praschberger, M.; Vogel, A.P.; et al. An open-label trial in Friedreich ataxia suggests clinical benefit with high-dose resveratrol, without effect on frataxin levels. J. Neurol. 2015, 262, 1344-1353. [CrossRef] [PubMed]

87. Voduc, N.; la Porte, C.; Tessier, C.; Mallick, R.; Cameron, D.W. Effect of resveratrol on exercise capacity: A randomized placebo-controlled crossover pilot study. Appl. Physiol. Nutr. Metab. 2014, 39, 1183-1187. [CrossRef]

88. Anton, S.D.; Embry, C.; Marsiske, M.; Lu, X.; Doss, H.; Leeuwenburgh, C.; Manini, T.M. Safety and metabolic outcomes of resveratrol supplementation in older adults: Results of a twelve-week, placebo-controlled pilot study. Exp. Gerontol. 2014, 57, 181-187. [CrossRef]

89. Chachay, V.S.; Macdonald, G.A.; Martin, J.H.; Whitehead, J.P.; O’Moore-Sullivan, T.M.; Lee, P.; Franklin, M.; Klein, K.; Taylor, P.J.; Ferguson, M.; et al. Resveratrol does not benefit patients with nonalcoholic fatty liver disease. Clin. Gastroenterol. Hepatol. 2014, 12, 2092-2103. [CrossRef]

90. Brown, V.A.; Patel, K.R.; Viskaduraki, M.; Crowell, J.A.; Perloff, M.; Booth, T.D.; Vasilinin, G.; Sen, A.; Schinas, A.M.; Piccirilli, G.; et al. Repeat dose study of the cancer chemopreventive agent resveratrol in healthy volunteers: Safety, pharmacokinetics, and effect on the insulin-like growth factor axis. Cancer Res. 2010, 70, 9003-9011. [CrossRef]

91. Rivastigmine. Micromedex Solutions. Truven Health Analytics, Inc. Ann Arbor, MI. Available online: http://www.micromedexsolutions.com (accessed on 18 October 2017).

92. Gómez-Zorita, S.; Fernández-Quintela, A.; Macarulla, M.T.; Aguirre, L.; Hijona, E.; Bujanda, L.; Milagro, F.; Martínez, J.A.; Portillo, M.P. Resveratrol attenuates steatosis in obese Zucker rats by decreasing fatty acid availability and reducing oxidative stress. Br. J. Nutr. 2012, 107, 202-210. [CrossRef] [PubMed]

93. Cho, I.J.; Ahn, J.Y.; Kim, S.; Choi, M.S.; Ha, T.Y. Resveratrol attenuates the expression of HMG-CoA reductase mRNA in hamsters. Biochem. Biophys. Res. Commun. 2008, 367, 190-194. [CrossRef] [PubMed]

94. Kulkarni, S.S.; Cantó, C. The molecular targets of resveratrol. Biochim. Biophys. Acta 2015, 1852, $1114-1123$. [CrossRef] [PubMed]

95. National Center for Biotechnology Information. PubChem Compound Database; CID = 5287554. Available online: https://pubchem.ncbi.nlm.nih.gov/compound/5287554\#section=Top (accessed on 18 October 2017).

96. Mahdinia, E.; Demirci, A.; Berenjian, A. Production and application of menaquinone-7 (vitamin K2): A new perspective. World J. Microbiol. Biotechnol. 2017, 33, 2. [CrossRef] [PubMed]

97. Shearer, M.J. Vitamin K. Lancet 1995, 345, 229-234. [CrossRef]

98. Suttie, J.W. The importance of menaquinones in human nutrition. Annu. Rev. Nutr. 1995, 15, $399-417$. [CrossRef] [PubMed]

99. Pucaj, K.; Rasmussen, H.; Moller, M.; Preston, T. Safety and toxicological evaluation of a synthetic vitamin K2, menaquinone-7. Toxicol. Mech. Methods 2011, 21, 520-532. [CrossRef]

100. Geleijnse, J.M.; Vermeer, C.; Grobbee, D.E.; Schurgers, L.J.; Knapen, M.H.; van der Meer, I.M.; Hofman, A.; Witteman, J.C. Dietary intake of menaquinone is associated with a reduced risk of coronary heart disease: The Rotterdam Study. J. Nutr. 2004, 134, 3100-3105. [CrossRef]

101. Luo, G.; Ducy, P.; McKee, M.D.; Pinero, G.J.; Loyer, E.; Behringer, R.R.; Karsenty, G. Spontaneous calcification of arteries and cartilage in mice lacking matrix GLA protein. Nature 1997, 386, 78-81. [CrossRef] [PubMed] 
102. Schurgers, L.J.; Spronk, H.M.; Soute, B.A.; Schiffers, P.M.; DeMey, J.G.; Vermeer, C. Regression of warfarin-induced medial elastocalcinosis by high intake of vitamin K in rats. Blood 2007, 109, 2823-2831. [CrossRef]

103. Koos, R.; Mahnken, A.H.; Mühlenbruch, G.; Brandenburg, V.; Pflueger, B.; Wildberger, J.E.; Kühl, H.P. Relation of oral anticoagulation to cardiac valvular and coronary calcium assessed by multislice spiral computed tomography. Am. J. Cardiol. 2005, 96, 747-749. [CrossRef] [PubMed]

104. Schurgers, L.J.; Aebert, H.; Vermeer, C.; Bültmann, B.; Janzen, J. Oral anticoagulant treatment: Friend or foe in cardiovascular disease? Blood 2004, 104, 3231-3232. [CrossRef] [PubMed]

105. Schurgers, L.J.; Cranenburg, E.C.; Vermeer, C. Matrix Gla-protein: The calcification inhibitor in need of vitamin K. Thromb. Haemost. 2008, 100, 593-603. [PubMed]

106. Buitenhuis, H.C.; Soute, B.A.; Vermeer, C. Comparison of the vitamins K1, K2 and K3 as cofactors for the hepatic vitamin K-dependent carboxylase. Biochim. Biophys. Acta 1990, 1034, 170-175. [CrossRef]

107. Schurgers, L.J.; Teunissen, K.J.; Hamulyák, K.; Knapen, M.H.; Vik, H.; Vermeer, C. Vitamin K-containing dietary supplements: Comparison of synthetic vitamin K1 and natto-derived menaquinone-7. Blood 2007, 109, 3279-3283. [CrossRef]

108. Vossen, L.M.; Schurgers, L.J.; van Varik, B.J.; Kietselaer, B.L.; Vermeer, C.; Meeder, J.G.; Rahel, B.M.; van Cauteren, Y.J.; Hoffland, G.A.; Rennenberg, R.J.; et al. Menaquinone-7 Supplementation to Reduce Vascular Calcification in Patients with Coronary Artery Disease: Rationale and Study Protocol (VitaK-CAC Trial). Nutrients 2015, 7, 8905-8915. [CrossRef]

109. Sato, T.; Schurgers, L.J.; Uenishi, K. Comparison of menaquinone-4 and menaquinone-7 bioavailability in healthy women. Nutr. J. 2012, 11, 93. [CrossRef]

110. Theuwissen, E.; Cranenburg, E.C.; Knapen, M.H.; Magdeleyns, E.J.; Teunissen, K.J.; Schurgers, L.J.; Smit, E.; Vermeer, C. Low-dose menaquinone-7 supplementation improved extra-hepatic vitamin K status, but had no effect on thrombin generation in healthy subjects. Br. J. Nutr. 2012, 108, 1652-1657. [CrossRef]

111. Mansour, A.G.; Hariri, E.; Daaboul, Y.; Korjian, S.; El Alam, A.; Protogerou, A.D.; Kilany, H.; Karam, A.; Stephan, A.; Bahous, S.A. Vitamin K2 supplementation and arterial stiffness among renal transplant recipients-a single-arm, single-center clinical trial. J. Am. Soc. Hypertens 2017, 11, 589-597. [CrossRef]

112. Emaus, N.; Gjesdal, C.G.; Almås, B.; Christensen, M.; Grimsgaard, A.S.; Berntsen, G.K.; Salomonsen, L.; Fønnebø, V. Vitamin K2 supplementation does not influence bone loss in early menopausal women: A randomised double-blind placebo-controlled trial. Osteoporos. Int. 2010, 21, 1731-1740. [CrossRef]

113. Caluwé, R.; Vandecasteele, S.; Van Vlem, B.; Vermeer, C.; De Vriese, A.S. Vitamin K2 supplementation in haemodialysis patients: A randomized dose-finding study. Nephrol. Dial. Transpl. 2014, 29, 1385-1390. [CrossRef] [PubMed]

114. Witt, D.M.; Clark, N.P.; Kaatz, S.; Schnurr, T.; Ansell, J.E. Guidance for the practical management of warfarin therapy in the treatment of venous thromboembolism. J. Thromb. Thrombolysis 2016, 41, 187-205. [CrossRef] [PubMed]

115. National Institute of Health (NIH). Office of Dietary Supplements. Magnesium, Fact Sheet for Health Professionals. Available online: https://ods.od.nih.gov/factsheets/Magnesium-HealthProfessional/ (accessed on 19 October 2017).

116. Office of the Surgeon General (US). Bone Health and Osteoporosis: A Report of the Surgeon General. Rockville (MD): Office of the Surgeon General (US). 2004. Available online: https://www.ncbi.nlm.nih.gov/ books/NBK45513/ (accessed on 19 October 2017).

117. Coudray, C.; Rambeau, M.; Feillet-Coudray, C.; Gueux, E.; Tressol, J.C.; Mazur, A.; Rayssiguier, Y. Study of magnesium bioavailability from ten organic and inorganic $\mathrm{Mg}$ salts in $\mathrm{Mg}$-depleted rats using a stable isotope approach. Magnes. Res. 2005, 18, 215-223. [PubMed]

118. Dickinson, H.O.; Nicolson, D.J.; Campbell, F.; Cook, J.V.; Beyer, F.R.; Ford, G.A.; Mason, J. Magnesium supplementation for the management of essential hypertension in adults. Cochrane Database Syst. Rev. 2006, 3, CD004640.

119. Kass, L.; Weekes, J.; Carpenter, L. Effect of magnesium supplementation on blood pressure: A meta-analysis. Eur. J. Clin. Nutr. 2012, 66, 411-418. [CrossRef]

120. Del Gobbo, L.C.; Imamura, F.; Wu, J.H.; de Oliveira Otto, M.C.; Chiuve, S.E.; Mozaffarian, D. Circulating and dietary magnesium and risk of cardiovascular disease: A systematic review and meta-analysis of prospective studies. Am. J. Clin. Nutr. 2013, 98, 160-173. [CrossRef] 
121. Bressendorff, I.; Hansen, D.; Schou, M.; Kragelund, C.; Brandi, L. The effect of magnesium supplementation on vascular calcification in chronic kidney disease-A randomised clinical trial (MAGiCAL-CKD): Essential study design and rationale. BMJ Open 2017, 7, e016795. [CrossRef]

122. Institute of Medicine (IOM); Food and Nutrition Board. Dietary Reference Intakes: Calcium, Phosphorus, Magnesium, Vitamin D and Fluoride. Washington, DC: National Academy Press. 1997. Available online: https://www.nap.edu/read/5776/chapter/8\#242 (accessed on 19 October 2017).

123. Torella, M.; Del Deo, F.; Grimaldi, A.; Iervolino, S.A.; Pezzella, M.; Tammaro, C.; Gallo, P.; Rappa, C.; De Franciscis, P.; Colacurci, N. Efficacy of an orally administered combination of hyaluronic acid, chondroitin sulfate, curcumin and quercetin for the prevention of recurrent urinary tract infections in postmenopausal women. Eur. J. Obs. Gynecol. Reprod. Biol. 2016, 207, 125-128. [CrossRef]

124. Cruz-Correa, M.; Shoskes, D.A.; Sanchez, P.; Zhao, R.; Hylind, L.M.; Wexner, S.D.; Giardiello, F.M. Combination treatment with curcumin and quercetin of adenomas in familial adenomatous polyposis. Clin. Gastroenterol. Hepatol. 2006, 4, 1035-1038. [CrossRef]

125. Paller, C.J.; Rudek, M.A.; Zhou, X.C.; Wagner, W.D.; Hudson, T.S.; Anders, N.; Hammers, H.J.; Dowling, D.; King, S.; Antonarakis, E.S.; et al. A phase I study of muscadine grape skin extract in men with biochemically recurrent prostate cancer: Safety, tolerability, and dose determination. Prostate 2015, 75, 1518-1525. [CrossRef]

126. la Porte, C.; Voduc, N.; Zhang, G.; Seguin, I.; Tardiff, D.; Singhal, N.; Cameron, D.W. Steady-State pharmacokinetics and tolerability of trans-resveratrol $2000 \mathrm{mg}$ twice daily with food, quercetin and alcohol (ethanol) in healthy human subjects. Clin. Pharm. 2010, 49, 449-454. [CrossRef]

127. Bahramsoltani, R.; Rahimi, R.; Farzaei, M.H. Pharmacokinetic interactions of curcuminoids with conventional drugs: A review. J. Ethnopharmacol. 2017, 209, 1-12. [CrossRef]

128. Romiti, N.; Tongiani, R.; Cervelli, F.; Chieli, E. Effects of curcumin on P-glycoprotein in primary cultures of rat hepatocytes. Life Sci. 1998, 62, 2349-2358. [CrossRef]

129. Anuchapreeda, S.; Leechanachai, P.; Smith, M.M.; Ambudkar, S.V.; Limtrakul, P.N. Modulation of P-glycoprotein expression and function by curcumin in multidrug-resistant human KB cells. Biochem. Pharm. 2002, 64, 573-582. [CrossRef]

130. Srivastava, K.C. Extracts from two frequently consumed spices-Cumin (Cuminum cyminum) and turmeric (Curcuma longa) - Inhibit platelet aggregation and alter eicosanoid biosynthesis in human blood platelets. Prostaglandins Leukot. Essent. Fat. Acids 1989, 37, 57-64. [CrossRef]

131. Huang, M.T.; Lysz, T.; Ferraro, T.; Abidi, T.F.; Laskin, J.D.; Conney, A.H. Inhibitory effects of curcumin on in vitro lipoxygenase and cyclooxygenase activities in mouse epidermis. Cancer Res. 1991, 51, 813-819.

132. Shah, B.H.; Nawaz, Z.; Pertani, S.A.; Roomi, A.; Mahmood, H.; Saeed, S.A.; Gilani, A.H. Inhibitory effect of curcumin, a food spice from turmeric, on platelet-activating factor- and arachidonic acid-mediated platelet aggregation through inhibition of thromboxane formation and Ca2+ signaling. Biochem. Pharm. 1999, 58, 1167-1172. [CrossRef]

133. Kim, D.C.; Ku, S.K.; Bae, J.S. Anticoagulant activities of curcumin and its derivative. BMB Rep. 2012, 45, $221-226$. [CrossRef]

134. Sanmukhani, J.; Satodia, V.; Trivedi, J.; Patel, T.; Tiwari, D.; Panchal, B.; Goel, A.; Tripathi, C.B. Efficacy and safety of curcumin in major depressive disorder: A randomized controlled trial. Phytother. Res. 2014, 28, 579-585. [CrossRef]

135. Wang, S.Y.; Duan, K.M.; Li, Y.; Mei, Y.; Sheng, H.; Liu, H.; Mei, X.; Ouyang, W.; Zhou, H.H.; Liu, Z.Q. Effect of quercetin on P-glycoprotein transport ability in Chinese healthy subjects. Eur. J. Clin. Nutr. 2013, 67, 390-394. [CrossRef]

136. Duan, K.M.; Wang, S.Y.; Ouyang, W.; Mao, Y.M.; Yang, L.J. Effect of quercetin on CYP3A activity in Chinese healthy participants. J. Clin. Pharm. 2012, 52, 940-946. [CrossRef]

137. Wu, L.X.; Guo, C.X.; Chen, W.Q.; Yu, J.; Qu, Q.; Chen, Y.; Tan, Z.R.; Wang, G.; Fan, L.; Li, Q.; et al. Inhibition of the organic anion-transporting polypeptide $1 \mathrm{~B} 1$ by quercetin: An in vitro and in vivo assessment. Br. J. Clin. Pharm. 2012, 73, 750-757. [CrossRef]

(C) 2019 by the authors. Licensee MDPI, Basel, Switzerland. This article is an open access article distributed under the terms and conditions of the Creative Commons Attribution (CC BY) license (http://creativecommons.org/licenses/by/4.0/). 